\title{
PENGARUH KEPUASAN KONSUMEN DAN KEPERCAYAAN MEREK PADA NIAT BERKUNJUNG KEMBALI HOTEL DI YOGYAKARTA
}

\author{
RR. Siti Muslikhah \\ Yuni Astuti \\ Mahyuddin \\ Jurusan Perhotelan Akademi Pariwisata “STIPARY” Yogyakarta
}

\begin{abstract}
This study aimed to examine the effect of customer satisfaction on revisit intention hotel in Yogyakarta, either directly or through the mediation of brand trust. Respondents in this study is that stayed in one-star hotels in Yogyakarta. To test the hypothesis quantitatively, the data obtained through a survey of 106 respondents. Sampling method nonprobability sampling with purposive sampling method. Validity testing performed by Confirmatory Factor Analysis (CFA) while reliability testing performed by the item to total correlation and Cronbach's alpha. Meanwhile, to test the effect among variables used hierarchical regression analysis and analysis of mediation Baron and Kenny (1986).

Results from this study is that customer satisfaction significant effect on brand trust, brand trust a significant effect on revisit intention. This study also proved that customer satisfaction significant influence on purchase intention of re-either directly or indirectly, that is mediated confidence in the brand. The role of mediation is partially.

Keywords: consumer satisfaction, brand trust, repurchase/revisit intention, mediation.
\end{abstract}

\section{PENDAHULUAN}

\section{Latar Belakang Masalah}

Persaingan industri perhotelan di wilayah Yogyakarta semakin ketat seiring munculnya hotel-hotel baru. Ketua Perhimpunan Hotel dan Restoran Indonesia (PHRI) DIY, Istidjab M Danunegoro, mengatakan, hingga saat ini jumlah hotel di wilayah Yogyakarta tercatat sebanyak 1.160 hotel. Sebanyak 60 di antaranya merupakan hotel bintang dengan 6.000-an kamar dan 1.100 hotel lainnya merupakan hotel kelas Melati dengan $\quad 12.660 \quad$ kamar. (http://travel.kompas.com). Biro Pusat Statistik Daerah Istimewa Yogyakarta, menginformasikan bahwa tingkat hunian hotel berbintang di DIY pada Bulan April 2014 adalah 51,35 persen sedangkan untuk hotel non bintang 25,34 persen.

Jumlah wisatawan yang menginap di hotel selama bulan April 2014 tercatat sebanyak 287.106 orang yang terdiri dari 272.948 orang wisatawan nusantara dan 14.158 orang wisatawan mancanegara. Dari jumlah tersebut menginap di hotel bintang sebanyak 99.110 orang dan 187.996 orang menginap di hotel non bintang atau akomodasi lain.

Berdasarkan data tersebut di atas menuntut para pelaku bisnis perhotelan untuk lebih memperhatikan berbagai aspek penting dalam menerapkan strategi pemasaran untuk memenangkan persaingan. Salah satu aspek penting tersebut adalah kepuasan pelanggan atau konsumen dan terbangunnya kepercayaan merek dari konsumen. Yang dapat dilakukan oleh perusahaan adalah dengan mempertahankan pelanggan yang ada, atau mengusahakan adanya loyalitas pelanggan, sehingga bisa menimbulkan niat untuk berkunjung kembali. Esensi hubungan pemasaran adalah untuk meningkatkan kompetisi yang berkelanjutan keuntungan melalui pendirian dan pengembangan hubungan yang abadi dengan pelanggan (Luk dan Yip, 2008). Pemasar selalu menginginkan terjadinya pembelian berkelanjutan terhadap produk dan layanan yang ditawarkan pada konsumen, sebagai konsekuensinya pemasar harus mampu memahami apa yang diinginkan dan dibutuhkan konsumen, dengan kata lain pemasar harus 
memahami perilaku konsumen (Dharmmesta, 1998).

Hubungan antara merek dan konsumen diperoleh dengan membangun kepuasan konsumen terhadap merek dan membangun kepercayaan konsumen terhadap merek (Blackstone, 2000). Lau dan Lee (1999) menyatakan bahwa kepercayaan terhadap merek adalah kemauan konsumen mempercayai merek dengan segala resikonya, karena ada harapan bahwa merek tersebut dapat memberikan hasil yang positif. Ada 3 (tiga) faktor utama pembentuk kepercayaan pada merek, yaitu karakteristik merek, karakteristik perusahaan, dan karakteristik hubungan merek dengan konsumen. Karakteristik merek meliputi : reputasi merek, sifat predictable merek dan kompetensi merek. Karakteristik perusahaan meliputi: kepercayaan terhadap perusahaan, reputasi perusahaan, motif perusahaan yang dipersepsikan oleh konsumen, dan integritas perusahaan. Sedangkan faktor ketiga adalah karakteristik hubungan merek dan konsumen yang mempengaruhi tingkat kepercayaan terhadap suatu merek yang meliputi: kesesuaian antara konsep diri dan kepribadian konsumen dengan sebuah merek, kepuasan menggunakan merek, kesukaan terhadap merek, pengalaman menggunakan merek, dan pengaruh teman atau lingkungan sosial terhadap pemilihan merek.

Lau dan Lee (1999) menyatakan merek merupakan faktor penting di dalam pasar, karena merupakan penghubung antara konsumen dan perusahaan. Bernd dan Patrick (2006) juga menjelaskan bahwa konsumen yang sadar terhadap sebuah merek tentunya akan terus mempercayai merek itu dalam melakukan pembelian, baik itu pembelian sekarang maupun pembelian ulang. Penelitian yang dilakukan Zboja dan Voorhees (2008) menemukan bahwa kepercayaan merek dan kepuasan memiliki pengaruh terhadap niat pembelian eceran. Dengan adanya kepuasan dan kepercayaan konsumen maka diharapkan memunculkan pengaruh positif yang kuat pada konsumen (Ranaweera and Prabhu, 2003) dan akhirnya memunculkan niat pembelian ulang.

\section{Rumusan Masalah}

Masalah utama dalam penelitian ini adalah "Apakah kepuasan konsumen berpengaruh positif pada niat berkunjung kembali apabila dimediasi oleh kepercayaan merek?"

\section{Tinjauan Pustaka}

a. Kepuasan Konsumen Satisfaction)

(Consumer

Kepuasan adalah tanggapan pelanggan atas terpenuhinya kebutuhan. Hal ini berarti menilai bahwa suatu bentuk keistimewaan dari suatu barang atau jasa atau barang atau jasa itu sendiri, memberikan tingkat kenyamanan yang terkait dengan pemenuhan suatu kebutuhan termasuk pemenuhan kebutuhan di bawah harapan atau pemenuhan kebutuhan melebihi harapan (Oliver, 1980). Kotler dan Keller (2009: 164) berpendapat bahwa kepuasan pelanggan merupakan fungsi harapan dan kinerja, yaitu evaluasi pelanggan terhadap kinerja produk atau layanan yang sesuai atau melampaui harapan.

\section{Kepercayaan Merek (Brand Trust)}

Kotler dan Keller (2009: 276) mendefinisikan merek adalah nama, istilah, tanda, simbol, desain, atau kombinasi dari merek, yang digunakan sebagai identitas produk atau servis dari penjual atau sekelompok penjual dan digunakan untuk membedakan dari kompetitor. Kepercayaan didefinisikan sebagai suatu keyakinan yang spesifik yang berhubungan dengan integritas, perhatian dari orang yang dipercaya untuk melakukan sesuatu yang dibutuhkan orang yang mempercayai dan konsistensi orang yang dipercaya dalam menyediakan produk tertentu (Gefen et al., 2003). Kepercayaan merek adalah rasa aman konsumen dalam interaksinya dengan suatu merek seperti didasarkan pada persepsi bahwa merek dapat dipercaya dan dapat dipertanggungjawabkan untuk menarik perhatian dan kesejahteraan konsumen (Delgado-Ballester, 2001).

\section{b. Niat Berkunjung Kembali (Revisit Intention)}

Niat berkunjung kembali atau bisa dikatakan niat pembelian ulang adalah salah satu faktor utama keberhasilan bisnis sejak banyaknya pesaing yang bermunculan serta biaya dan pengolahan konsumen baru menjadi semakin tinggi. Beberapa studi empiris menunjukkan bahwa niat pembelian ulang memengaruhi perilaku pembelian secara actual di masa depannya (Weiqaiyan, 2005). Jones dan 
Sasser (1995) seperti dikutip oleh Yang (2009) menyatakan bahwa pembelian ulang adalah sebuah perilaku dasar setelah konsumen mendapatkan kepuasan dalam pembelian.

\section{c. Penelitian Terdahulu}

Beberapa penelitian terdahulu meneliti variabel-variabel kepuasan konsumen, kepercayaan merek, dan niat pembelian ulang, yang ditampilkan pada Tabel 5 menjadi acuan dalam penelitian ini.

\section{Tabel 5}

\section{Penelitian Terdahulu yang Menjadi Acuan}

\begin{tabular}{|c|c|c|c|}
\hline Peneliti & Variabel & Produk & Hasil Penelitian \\
\hline $\begin{array}{l}\text { Delgado- } \\
\text { Ballester and } \\
\text { Munuera- } \\
\text { Aleman (2005) }\end{array}$ & $\begin{array}{l}\text { Kepuasan, } \\
\text { kepercayaan merek, } \\
\text { loyalitas merek, dan } \\
\text { ekuitas merek }\end{array}$ & $\begin{array}{l}\text { Shampo } \\
\text { dan Bir } \\
\text { (Beer) }\end{array}$ & $\begin{array}{l}\text { Kepercayaan merek berpengaruh } \\
\text { positif pada loyalitas merek dan } \\
\text { ekuitas merek tetapi tidak secara } \\
\text { penuh memediasi kepuasan dengan } \\
\text { loyalitas merek. }\end{array}$ \\
\hline $\begin{array}{l}\text { Zboja and } \\
\text { Voorhees } \\
\text { (2006) }\end{array}$ & $\begin{array}{l}\text { Kepuasan dan } \\
\text { kepercayaan pada } \\
\text { merek, kepercayaan } \\
\text { dan kepuasan pada } \\
\text { pengecer serta niat } \\
\text { pembelian ulang }\end{array}$ & $\begin{array}{l}\text { komputer } \\
\text { dan mesin } \\
\text { foto kopi }\end{array}$ & $\begin{array}{l}\text { Kepercayaan merek dan kepuasan } \\
\text { memiliki dampak pada niat } \\
\text { pembelian ulang yang dimediasi } \\
\text { melalui kepercayaan dan kepuasan } \\
\text { pengecer }\end{array}$ \\
\hline $\begin{array}{l}\text { Luk and Yip } \\
\text { (2008) }\end{array}$ & $\begin{array}{l}\text { Kepuasan konsumen, } \\
\text { kepercayaan merek, } \\
\text { perilaku pembelian, } \\
\text { promosi pembelian } \\
\text { sebagai variabel } \\
\text { moderator }\end{array}$ & Fashion & $\begin{array}{l}\text { Kepuasan konsumen mempunyai } \\
\text { pengaruh positif pada kepercayaan } \\
\text { merek. Pengaruh kepercayaan } \\
\text { merek pada perilaku pembelian } \\
\text { diperkuat oleh promosi penjualan } \\
\text { sebagai variabel moderator }\end{array}$ \\
\hline
\end{tabular}

Lanjutan Tabel 5

\begin{tabular}{|l|l|l|l|}
\hline \multicolumn{1}{|c|}{ Peneliti } & \multicolumn{1}{c|}{ Variabel } & \multicolumn{1}{c|}{ Produk } & \multicolumn{1}{c|}{ Hasil Penelitian } \\
\hline Ha et al. (2010) & $\begin{array}{l}\text { Kepuasan, harapan } \\
\text { yang disesuaikan, } \\
\text { kepercayaan, sikap } \\
\text { positif, niat } \\
\text { pembelian ulang }\end{array}$ & $\begin{array}{l}\text { Pelayanan } \\
\text { travel } \\
\text { secara } \\
\text { online }\end{array}$ & $\begin{array}{l}\text { Terdapat pengaruh positif dan } \\
\text { signifikan kepuasan pada niat } \\
\text { pembelian ulang yang dimediasi } \\
\text { kepercayaan merek }\end{array}$ \\
\hline $\begin{array}{l}\text { Raza } \text { et al. } \\
(2012)\end{array}$ & $\begin{array}{l}\text { Kualitas Pelayanan, } \\
\text { Nilai yang } \\
\text { Dipersepsikan, } \\
\text { Kepuasan dan Niat } \\
\text { Berkunjung Kembali }\end{array}$ & $\begin{array}{l}\text { Pelayanan } \\
\text { Jasa Hotel }\end{array}$ & $\begin{array}{l}\text { Terdapat pengaruh positif dan } \\
\text { signifikan pada hubungan antara } \\
\text { kualitas pelayanan, nilai yang } \\
\text { dipersepsikan dan kepuasan pada } \\
\text { niat berkunjung kembali di industri } \\
\text { perhotelan di Pakistan. }\end{array}$ \\
\hline
\end{tabular}

d. Hubungan antara Kepuasan Konsumen dan Kepercayaan Merek

Blackstone (2000) menjelaskan bahwa dalam hubungan antara merek dan konsumen yang sukses terdapat dua komponen yang tidak bisa dipisahkan yaitu kepercayaan terhadap merek dan kepuasan pelanggan pada merek. Selnes (1998) menyatakan bahwa kepuasan mempunyai dampak yang signifikan pada kepercayaan. Christou (2004) juga telah menemukan bahwa kepuasan pelanggan dengan jasa perhotelan berkorelasi positif kepada kepercayaan pelanggan dalam merek perhotelan. Hipotesis pertama yang diajukan adalah sebagai berikut:
H1 : Kepuasan konsumen berpengaruh positif pada kepercayaan merek

\section{e. Hubungan antara Kepercayaan Merek dan Niat Berkunjung Kembali}

Zboja dan Voorhees (2006) menemukan bahwa kepercayaan mempunyai pengaruh positif langsung pada niat pembelian ulang. Kepercayaan merupakan prediktor yang signifikan pada niat pembelian yang akan datang (Rosenbaum et al. 2006). Kim et al. (2009) menemukan bahwa kepercayaan berpengaruh secara signifikan pada niat berkunjung kembali (revisit intention) turis. 
Hipotesis kedua yang diajukan adalah sebagai berikut:

H2 : Kepercayaan merek berpengaruh positif pada niat berkunjung kembali.

\section{f. Hubungan antara Kepuasan Konsumen dan Niat Berkunjung Kembali}

Weqaiyan (2005) menemukan bahwa niat pembelian ulang merupakan hasil dari konsumen yang terpuaskan. Hal ini juga sesuai dengan penelitian Oliver (1999) bahwa semakin tinggi kepuasan konsumen akan mengarahkan pada semakin tingginya tingkat niat pembelian ulang. Hasil penelitian Zboja dan Voorhess (2006) dan Ha et al. (2010) juga menunjukkan pengaruh positif kepuasan pada niat pembelian ulang. Kim et al. (2009) menemukan bahwa kepuasan berpengaruh secara signifikan pada niat berkunjung kembali (revisit intention) turis. Raza et al. (2012) juga menemukan bahwa kepuasan berpengaruh pada niat berkunjung kembali pada industri perhotelan di Pakistan. Hipotesis ketiga yang diajukan adalah sebagai berikut:
H3 : Kepuasan konsumen berpengaruh positif pada niat berkunjung kembali.

g. Kepercayaan Merek Memediasi Hubungan Kepuasan Konsumen pada Niat Berkunjung Kembali

Menurut Luk dan Yip (2008) pengaruh kepuasan pada perilaku pembelian dalam hal ini niat pembelian ulang tidak secara langsung tetapi melalui kepercayaan pada merek. Penelitian yang dilakukan Zboja dan Voorhees (2006) menjelaskan bahwa kepercayaan merek dan kepuasan memiliki dampak pada niat pembelian ulang yang dimediasi melalui kepercayaan dan kepuasan pengecer. Hipotesis keempat yang diajukan adalah sebagai berikut:

H4 : Kepercayaan merek memediasi pengaruh kepuasan konsumen pada niat berkunjung kembali.

\section{h. Model Penelitian}

Model penelitian mengacu pada Luk dan Yip (2008), peneliti melakukan modifikasi pengurangan dan penambahan model seperti pada Gambar 1.

\section{Gambar 1}

\section{Model Penelitian}

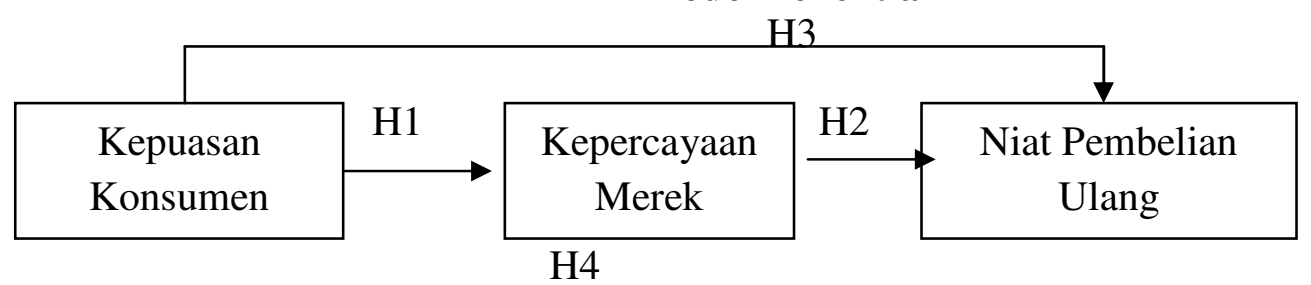

Sumber: Dimodifikasi dari Luk dan Yip (2008); Ha, et al. (2010)

\section{B. METODE PENELITIAN}

Penelitian ini mengunakan metode survey dengan menanyakan kepada responden menggunakan kuesioner yang dibagikan secara langsung kepada responden penelitian (Neuman, 2006: 36). Data untuk mengukur masing-masing variabel penelitian dikumpulkan dengan menggunakan kuesioner yang berisi item-item pertanyaan yang menggambarkan variabel yang diteliti yaitu: kepuasan konsumen, kepercayaan merek, dan niat berkunjung kembali.

Metode pengambilan sampel dilakukan secara nonprobability sampling karena tidak ada data mengenai total populasi dan sampling frame sehingga probabilitas untuk memilih elemen dari populasi tidak diketahui (Cooper dan Schindler, 2011: 384). Metode nonprobability sampling yang digunakan adalah purposive sampling yaitu pengambilan sampel yang didasarkan pada pertimbangan untuk menyesuaikan diri dengan beberapa kriteria penelitian agar dapat meningkatkan ketepatan sampel (Cooper dan Schindler, 2011: 385).

Teknik purposive sampling dilakukan berdasarkan kriteria konsumen yang pernah menginap di hotel berbintang minimal satu kali. Kriteria yang lain bahwa responden adalah orang yang merasakan pelayanan hotel secara langsung dan merasakan keuntungan dan kerugian menginap di hotel serta merek atau nama hotel yang responden tersebut pernah menginap sebelumnya.

\section{Metode Analisis}

Pengujian hipotesis dalam penelitian ini diuji dengan hierarchical regression analysis. Pengujian dilakukan dengan mengacu pada 
model yang dikembangkan oleh Baron dan Kenny (1986) Menurut Baron dan Kenny (1986) variabel mediasi memiliki hubungan kausal dengan variabel independen dan variebal dependen yang ditunjukkan dalam Gambar 2 .

Gambar 2

\section{Model Analisis Mediasi}

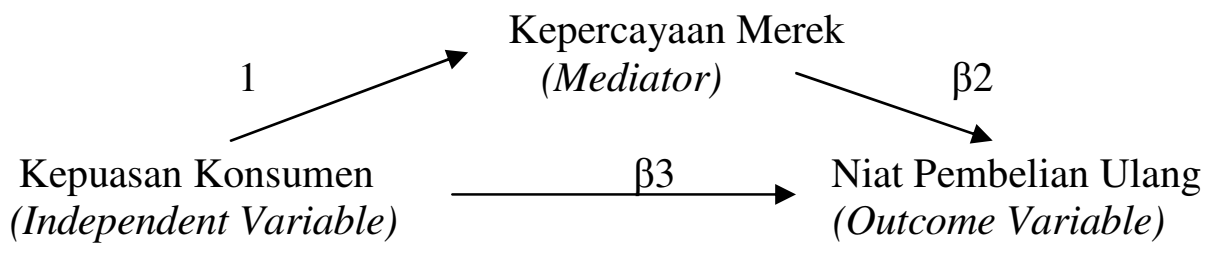

Sumber: Baron and Kenny (1986)

\section{HASIL DAN PEMBAHASAN \\ 1. Hasil Pengumpulan Data}

Pengumpulan data dengan cara penulis mencari responden di tempat-tempat wisata dan juga di perguruan tinggi serta melalui email dan juga mengirimkan kuesioner melalui pos. Dengan cara tersebut sebagian kuesioner diberikan secara langsung, untuk kuesioner yang tidak diberikan secara langsung yaitu melalui email dan pos ada yang tidak kembali. Kuesioner yang disebarkan seluruhnya berjumlah 250 kuesioner. Dari kuesioner tersebut yang kembali ada 150 kuesioner, dan dari 150 kuesioner tersebut yang bisa diolah adalah 106 kuesioner karena ada beberapa kuesioner yang tidak bisa diolah karena data kurang lengkap.

\section{Karakteristik Responden}

Data diperoleh dari 106 responden yang dikelompokkan berdasarkan usia, jenis kelamin atau gender, pendidikan, merek hotel tempat menginap, lama menginap, biaya hidup, serta kota asal. Karakteristik Responden Berdasarkan Usia, responden paling banyak adalah yang berusia 34-51tahun yaitu 51 orang dengan persentase 48,1 \%. Karakteristik Responden Berdasarkan Jenis Kelamin atau Gender, responden paling banyak adalah yang berjenis kelamin wanita yaitu 55 orang dengan persentase 51,9 \%. Karakteristik Responden Berdasarkan Pendidikan, reponden paling banyak adalah yang yang berpendidikan S1 yaitu 46 orang dengan persentase $43,4 \%$. Karakteristik responden berdasarkan lama menginap, responden paling banyak adalah yang menginap satu kali yaitu 61 orang dengan persentase 57,5 \%. Karakteristik responden berdasarkan biaya hidup, responden paling banyak adalah yang biaya hidup per bulan 1-2 juta jumlah 33 orang dengan persentase $31,1 \%$. Karakteristik responden berdasarkan kota asal, responden berasal dari beberapa kota khususnya dari Jawa dan paling banyak adalah berasal dari kota Yogyakarta yaitu dengan jumlah 29 orang dengan persentase 27,4 \%. Pada Tabel 5 dapat dilihat karakteristik responden berdasarkan merek atau nama hotel. Responden paling banyak adalah yang menginap di Hotel Cakra Kusuma 19 orang dengan persentase $17,9 \%$.

Tabel 5

Karakteristik Responden Berdasarkan Merek

\begin{tabular}{|c|c|c|}
\hline Merek (Nama Hotel) & $\begin{array}{c}\text { Frekuensi } \\
\text { (orang) }\end{array}$ & Persentase (\%) \\
\hline Abadi Hotel & 2 & 1,9 \\
\hline Arjuna & 2 & 1,9 \\
\hline Cakra Kembang & 1 & 0,9 \\
\hline Cakra Kusuma & 19 & 17,9 \\
\hline Cavinton & 4 & 3,8 \\
\hline Eastparc & 2 & 1,9 \\
\hline Fave Hotel & 7 & 6,6 \\
\hline
\end{tabular}


JURNAL MANAJEMEN VOL 5 NO.1 JUNI 2015

\begin{tabular}{|c|c|c|}
\hline Grage Hotel & 2 & 1,9 \\
\hline Grand Aston & 2 & 1,9 \\
\hline Griya Persada & 11 & 10,4 \\
\hline Hyatt Regency & 1 & 0,9 \\
\hline Ibis Style & 2 & 1,9 \\
\hline Inna Natour Garuda & 8 & 7,5 \\
\hline Jambuluwuk & 7 & 6,6 \\
\hline Jayakarta & 1 & 0,9 \\
\hline Jogjakarta Plaza Hotel & 1 & 0,9 \\
\hline Hotel Matahari & 1 & 0,9 \\
\hline Melia Purosani & 4 & 3,8 \\
\hline Merapi Merbabu & 1 & 0,9 \\
\hline Mutiara & 5 & 4,7 \\
\hline Novotel & 4 & 3,8 \\
\hline Ross In & 2 & 1,9 \\
\hline Royal Ambarrukmo & 4 & 3,8 \\
\hline Sahid Raya & 1 & 0,9 \\
\hline Santika & 7 & 6,6 \\
\hline Saphir & 1 & 0,9 \\
\hline Sheraton Mustika & 2 & 1,9 \\
\hline The Sahid Rich & 2 & 1,9 \\
\hline Jumlah & $\mathbf{1 0 6}$ & $\mathbf{1 0 0}$ \\
\hline
\end{tabular}

Sumber : Data diolah

\section{Hasil Uji Validitas dan Reliabilitas}

Pengukuran convergent validity suatu instrumen riset dikatakan memenuhi convergent validity jika nilai loading setiap item atau indikator terhadap konstruk yang diukurnya adalah 0.40 , analisis faktor dapat dilakukan karena matrik data memiliki korelasi yang cukup agar dapat dilakukan analisis faktor (Hair et al, 2006; 114). Hal tersebut ditunjukkan dengan nilai KMO yang lebih dari 0,50 dan Barlett's test of sphericty signifikan pada 0,000. Adapun hasil dari uji validitas dengan menggunakan metode Varimax dalam confirmatory factor analysis. Hasil perhitungan confirmatory factor analysis yang disajikan menunjukkan bahwa convergent validity bisa diterima karena memiliki factor loading yang lebih besar dari 0.40 dan signifikan pada level kepercayaan 95\%. Hasil dari analisis faktor terbentuk 3 (tiga) faktor dengan faktor loading di atas 0,5 .
Pengujian reliabilitas konstruk diukur dengan item to total correlation dan Cronbach's alpha, yang mencerminkan konsistensi internal alat. Cronbach's alpha dihitung dalam bentuk rata-rata interkorelasi antar item yang mengukur konstruk. Semakin dekat nilai Conbrach's alpha dengan satu semakin tinggi konsistensi internal reliabilitas. Rules of thumb untuk Cronbach's alpha yang digunakan harus lebih besar dari nilai 0.70 , meskipun nilai 0.60 masih dapat diterima (Hair et al., 2006: 137). Hasil uji reliabilitas menunjukkan bahwa variabel kepuasan konsumen Cronbach's alpha 0,834, variabel kepercayaan merek Cronbach's alpha 0,836 , variabel niat berkunjung kembali Cronbach's alpha 0,874, sehingga ketiga variabel tersebut memenuhi uji reliabilitas.

\section{Pengujian Hipotesis 1 (H1)}

Hipotesis 1 menyatakan bahwa kepuasan konsumen berpengaruh positif pada kepercayaan merek. Hasil pengujian hipotesis 1 dapat dilihat pada Tabel 9. 
Tabel 9

Regresi Pengaruh Kepuasan Konsumen pada Kepercayaan Merek

\begin{tabular}{|c|c|c|c|c|c|}
\hline $\begin{array}{c}\text { Variabel } \\
\text { Independen }\end{array}$ & $\begin{array}{c}\text { Variabel } \\
\text { Dependen }\end{array}$ & Beta & T hitung & Sig & Keterangan \\
\hline $\begin{array}{c}\text { Kepuasan } \\
\text { konsumen }\end{array}$ & $\begin{array}{c}\text { Kepercayaan } \\
\text { merek }\end{array}$ & 0,518 & 6,173 & 0,000 & Signifikan \\
\hline
\end{tabular}

Sumber : Data diolah

Hasil pengujian di Tabel 4.11 diperoleh $\mathrm{t}_{\text {hitung }}=6,173$ dengan tingkat signifikansi 0,000 dan beta 0,518. Hasil pengujian mendukung hipotesis bahwa kepuasan konsumen berpengaruh positif pada kepercayaan merek (H1), sehingga dapat disimpulkan bahwa Hipotesis 1 terbukti dan mendukung hasil penelitian yang dilakukan oleh Delgado dan Munuera (2001); Zboja dan Voorhees (2006); Luk and Yip (2008); serta Ha et al. (2010). Hal tersebut menunjukkan jika kepuasan konsumen

meningkat maka kepercayaan merek cenderung meningkat. Konsumen yang puas akan suatu merek dapat menyebabkan konsumen semakin percaya akan merek tersebut, dengan kata lain konsumen akan mempunyai tingkat kepercayaan yang tinggi apabila puas akan suatu merek.

\section{Pengujian Hipotesis 2 (H2)}

Hipotesis 2 menyatakan bahwa kepercayaan merek berpengaruh positif pada niat berkunjung kembali. Hasil pengujian dapat dilihat pada Tabel 10 .

Tabel 10

Regresi Pengaruh Kepercayaan Merek Pada Niat Berkunjung Kembali

\begin{tabular}{|c|c|c|c|c|c|}
\hline $\begin{array}{c}\text { Variabel } \\
\text { Independen }\end{array}$ & $\begin{array}{c}\text { Variabel } \\
\text { Dependen }\end{array}$ & Beta & T hitung & Sig & Keterangan \\
\hline $\begin{array}{c}\text { Kepercayaan } \\
\text { merek }\end{array}$ & $\begin{array}{c}\text { Niat } \\
\text { Berkunjung } \\
\text { Kembali }\end{array}$ & 0,584 & 7,343 & 0,000 & Signifikan \\
\hline
\end{tabular}

Sumber : Data diolah

Hasil pengujian di Tabel 4.11 diperoleh $\mathrm{t}_{\text {hitung }}=7,343$ dengan tingkat signifikansi 0,000 dan beta 0,584 . Hasil pengujian mendukung hipotesis bahwa kepercayaan merek berpengaruh positif pada niat berkunjung kembali (H2), sehingga dapat disimpulkan bahwa Hipotesis 2 terbukti dan mendukung hasil penelitian yang dilakukan oleh $\mathrm{Ha}$ et al. (2010). Hal tersebut menunjukkan jika kepercayaan merek meningkat maka niat pembelian ulang cenderung meningkat. Jika konsumen percaya pada suatu merek, maka cenderung mempunyai niat untuk melakukan pembelian ulang merek produk tersebut. Semakin konsumen percaya pada suatu merek maka semakin tinggi niat konsumen untuk membeli ulang merek tersebut.

\section{Pengujian Hipotesis 3 (H3)}

Hipotesis 3 menyatakan bahwa kepuasan konsumen berpengaruh positif pada niat berkunjung kembali. Hasil pengujian dapat dilihat pada Tabel 11.

\section{Tabel 11}

\section{Regresi Pengaruh Kepuasan Konsumen Pada Niat Berkunjung Kembali}

\begin{tabular}{|c|c|c|c|c|c|}
\hline $\begin{array}{c}\text { Variabel } \\
\text { Independen }\end{array}$ & $\begin{array}{c}\text { Variabel } \\
\text { Dependen }\end{array}$ & Beta & T hitung & Sig & Keterangan \\
\hline $\begin{array}{c}\text { Kepuasan } \\
\text { Konsumen }\end{array}$ & $\begin{array}{c}\text { Niat } \\
\text { Berkunjung } \\
\text { Kembali }\end{array}$ & 0,595 & 7,557 & 0,000 & Signifikan \\
\hline
\end{tabular}

Sumber : Data diolah

Hasil pengujian di Tabel 4.13 diperoleh $\mathrm{t}_{\text {hitung }}=7,557$ dengan tingkat signifikansi 0,000 dan beta 0,595. Hasil pengujian mendukung hipotesis bahwa kepuasan konsumen 
berpengaruh positif pada niat berkunjung kembali (H3), sehingga dapat disimpulkan bahwa Hipotesis 3 terbukti dan mendukung hasil penelitian yang dilakukan oleh Hellier et al. (2003) dan Ha et al. (2010). Hal tersebut menunjukkan bahwa konsumen yang puas akan suatu merek cenderung mempunyai niat untuk melakukan pembelian ulang merek tersebut. Hasil pengujian hipotesis ini juga mendukung hasil penelitian Raza et al. (2012) bahwa kepuasan berpengaruh positif pada niat berkunjung kembali di industri perhotelan di Pakistan.

\section{Pengujian Hipotesis $4(\mathbf{H 4})$}

Hipotesis 4 menyatakan bahwa kepercayaan merek memediasi pengaruh kepuasan konsumen pada berkunjung kembali. Untuk menguji hipotesis 4 dan untuk dapat ditentukan apakah variabel kepercayaan merek memediasi pengaruh kepuasan konsumen pada niat berkunjung kembali dilakukan hierarchical regression analysis yang dikemukakan oleh Baron and Kenny (1986). Ringkasan hasil dari analisis yang telah dilakukan dapat dilihat pada Tabel 12.

Tabel 12

Hasil Analisis Regresi untuk Menentukan Mediasi

\begin{tabular}{|c|c|c|c|c|}
\hline \multicolumn{5}{|c|}{$\begin{array}{c}\text { Pengaruh Kepuasan Konsumen pada Niat Berkunjung Kembali yang Dimediasi } \\
\text { oleh Kepercavaan Merek }\end{array}$} \\
\hline \multicolumn{4}{|c|}{$\begin{array}{c}\text { Tahap 1: } \\
\text { Pengaruh kepuasan konsumen pada niat berkunjung kembali }\end{array}$} & Keterangan \\
\hline & Beta & Nilai $\mathrm{t}$ & Nilai Signifikansi & \\
\hline $\mathrm{KK} \rightarrow \mathrm{RI}$ & 0,595 & 7,557 & 0,000 & Syarat 1 terpenuhi \\
\hline \multicolumn{5}{|c|}{$\begin{array}{c}\text { Tahap 2: } \\
\text { Pengaruh kepuasan konsumen pada kepercayaan merek }\end{array}$} \\
\hline & Beta & Nilai t & Nilai Signifikansi & \\
\hline $\mathrm{KK} \rightarrow \mathrm{KM}$ & 0,518 & 6,173 & 0,000 & Syarat 2 terpenuhi \\
\hline \multicolumn{5}{|c|}{$\begin{array}{c}\text { Tahap 3: } \\
\text { Pengaruh kepercayaan merek pada niat berkunjung kembali }\end{array}$} \\
\hline & Beta & Nilai t & Nilai Signifikansi & \\
\hline $\mathrm{KM} \rightarrow \mathrm{RI}$ & 0,584 & 7,343 & 0,000 & Syarat 3 terpenuhi \\
\hline \multicolumn{5}{|c|}{$\begin{array}{c}\text { Hasil: } \\
\text { Pengaruh kepuasan konsumen dan kepercayaan merek pada niat berkunjung } \\
\text { kembali }\end{array}$} \\
\hline & Beta & Nilai t & \begin{tabular}{|l|} 
Nilai Signifikansi \\
\end{tabular} & \\
\hline $\mathrm{KK} \rightarrow \mathrm{RI}$ & 0,400 & 4,721 & 0,000 & Syarat 4 terpenuhi \\
\hline $\mathrm{KM} \rightarrow \mathrm{RI}$ & 0,377 & 4,450 & 0,000 & \\
\hline
\end{tabular}

Sumber: Data diolah

Berdasarkan Tabel 12 dapat dilihat bahwa hasil analisis stastistik dengan menggunakan hierarchical regression analysis menunjukkan bahwa kepercayaan merek terbukti memediasi hubungan antara kepuasan konsumen pada niat berkunjung kembali. Dapat diambil kesimpulan bahwa kepercayaan merek memediasi pengaruh kepuasan konsumen pada niat berkunjung kembali, sehingga hipotesis 4 terdukung. Peran mediasi disini adalah mediasi secara parsial.

\section{KESIMPULAN}

Penelitian ini bertujuan untuk menguji pengaruh kepuasan konsumen pada niat berkunjung kembali yang dimediasi oleh kepercayaan merek. Adapun hasil penelitian dapat disimpulkan sebagai berikut:

1. Kepuasan konsumen terbukti berpengaruh positif pada kepercayaan merek, mendukung hasil penelitian yang dilakukan oleh Delgado dan Munuera (2001); Zboja dan Voorhees (2006); Luk dan Yip (2008); serta Ha et al. (2010). Hal tersebut menunjukkan bahwa konsumen yang puas akan suatu merek dapat menyebabkan konsumen semakin percaya akan merek tersebut. Dalam hal ini adalah konsumen hotel yang puas terhadap hotel tersebut maka konsumen tersebut akan percaya terhadap nama hotel atau merek hotel tersebut. 
2. Kepercayaan merek terbukti berpengaruh positif pada niat berkunjung kembali, mendukung hasil penelitian yang dilakukan oleh Ha et al. (2010). Hal ini menunjukkan bahwa jika konsumen percaya pada suatu merek dalam hal ini nama hotel, maka cenderung mempunyai niat untuk berkunjung kembali ke hotel tersebut.

3. Kepuasan konsumen terbukti berpengaruh positif pada niat berkunjung kembali, mendukung hasil penelitian yang dilakukan oleh Anderson dan Sullivan (1993); Hellier et al. (2003); Ha et al. (2010); Penelitian Raza et al. (2012) juga menyatakan bahwa kepuasan berpengaruh positif pada niat berkunjung kembali di industri perhotelan di Pakistan. Hal ini menunjukkan konsumen yang puas akan suatu merek maka akan semakin tinggi niat konsumen untuk membeli ulang merek tersebut atau dalam penelitian ini berkunjung kembali ke hotel.

4. Kepercayaan merek terbukti berperan sebagai mediasi secara parsial antara pengaruh kepuasan konsumen pada niat berkunjung kembali, sesuai dengan penelitian Ha et al. (2010) bahwa terdapat pengaruh positif dan signifikan kepuasan pada niat pembelian ulang yang dimediasi oleh kepercayaan merek. Kepercayaan juga merupakan mediasi parsial dalam hubungan antara kepuasan dan loyalitas dalam penelitiannya Paparoidamis dan Caceres (2005).

\section{E. DAFTAR PUSTAKA}

Anderson, W. E. and Sullivan, M. V. (1993), "The Antecendents and Consequences of Customer Satisfaction for Firm," Marketing Science, Vol. 12, No. 2, pp. 125-143.

Baron, R. M. and Kenny, D. A. (1986), "The Moderator-Mediator Variable Distinction in Social Psychological Research: Conceptual, Strategic, and Statistical Considerations," Journal of Personality and Social Psychology, Vol. 51, No. 6, pp. 1173-1182.
Bernd, H. S. and Patrick, G. (2006), "Are Brands Forever? How Brand Knowledge and Relationship Affect Current and Future Purchase," Journal of Product and Brand Management, Vol. 15, No. 2, pp. 98-105.

Biro Pusat Statistik (2014), “Tingkat Penghunian Kamar (TPK) Hotel Bintang

D.I. Yogyakarta Bulan April 2014 Sebesar 51,35 Persen," Berita Resmi Statistik D.I. Yogyakarta, No. 32/06/34/Th.XVI

Blackstone, M. (2000), "Observation: Building Brand Equity by Managing The Brand Relationship, " Journal of Advertising Research, Vol. 40, No. 6, pp. 101-105.

Cooper, D. R. and Schindler, P. S. (2010), Business Research Methods, $11^{\text {th }}$ ed. New York: Mc Graw Hill Book Co.

Christou, E . (2004), "The Impact of Trust on Brand Loyalty: Evidence from The Hospitality Industry," www.traveldailynews.gr

Delgado-Ballester, E and Munuera-Aleman, J. L. (2001), "Brand Trust in the Context Consumer Loyalty," European Journal of Marketing, Vol. 35, No. 11/12, pp. 12381258.

Delgado-Ballester, E. (2003), "Development and Validation of a Brand Trust Scale," International Journal of Market Research, Vol. 45, No. 1, pp. 35-54.

Delgado-Ballester, E and Munuera-Aleman, J. L. (2005), "Does Brand Trust Matter to Brand Equity?" Journal of Product and Brand Management. Vol. 14, No.3 pp. 187-196.

Dharmmesta, B. S. (1998), “ Teknologi Informasi Dalam Pemasaran: Implikasi Dalam Pendidikan Pemasaran," Jurnal Ekonomi dan Bisnis Indonesia, Vol. 13, No. 3, pp. 116-125. 
Ferrand, A.; Robinson, L. and Valette-Florence, P. (2010), "The Intention-to Repurchase Paradox: A Case of the Health and Fitness Industry," Journal of Sport Management, Vol. 24, pp. 83-105.

Gefen, D.; Karahanna, E. and Straub, D. W. (2003), "Trust and TAM in Online Shopping: An Integrated Model," MIS Quarterly, Vol. 27, No. 1, March, pp. 5190.

Ha, H-Y.; Janda, S. and Muthaly, S. K. (2010), "A New Understanding of Satisfaction Model in E-Re-Purchase Situation," European Journal of Marketing, Vol. 44, No. 7/8, pp. 997-1016.

Ha, H-Y.; Muthaly, S. K. and Akamavi, R. K. (2010), "Alternative Explanations of Online Repurchasing Behavioral Intentions: A Comparison Study of Korean and UK Young Customers," European Journal of Marketing, Vol. 44, No. 6, pp. 874-904.

Hair, J. F.; Anderson, R. E., Tatham, R. L. and Black, W. C. (2006), Multivariate Data Analysis, $5^{\text {th }}$ ed. Upper Saddle River, New Jersey: Prentice Hall International, Inc.

Hellier, P. K.; Geursen, G. M.; Carr, R. and Rickard, J. A. (2003), "Customer Repurchase Intention: A General Structural Equation Model," European Journal of Marketing, Vol. 37, pp. 17621800.

Jin, Y. and Su, M. (2009), "Recommendation and Repurchase Intention Thresholds: A Joint Heterogeneity Response Estimation," International Journal of Research in Marketing, Vol. 26, pp. 245255.

Kim, T.; Kim, W. G. and Bumm-Kim, H. (2009), "The Effects of Perceived Justice on Recovery Satisfaction, Trust, WordOf-Mouth, and Revisit Intention in Upscale Hotels," Tourism Management, Vol. 30, pp. 51-62.
Kotler, P. and Keller, K. L. (2009), Marketing Management, $13^{\text {th }}$ ed. Upper Saddle River, New Jersey: Pearson Education, Inc.

Lau, G. T. and Lee, S. H. (1999), “ Consumer Trust in Brand and The Link to Brand Loyalty," Journal of Market Focused Management, Vol. 4, pp. 341-370.

Luk, S. T. K. and Yip, L. S. C. (2008), "The Moderator Effect of Monetary Sales Promotion on The Relationship Between Brand Trust and Purchase Behaviour," Journal of Brand Management, Vol. 15, No. 6, pp. 452-464.

Neuman, W. L. (2006), Social Research Methods: Qualitative and Quantitative Approach, $6^{\text {th }}$ ed. Boston: Pearson International Edition.

Oliver, R. L. (1980), "A Cognitive Model of Antecedents and Consequences of Satisfaction Decisions," Journal of Marketing Research, Vol. 17, November, pp. 460-469.

Oliver, R. L. (1999), "Whence Consumer Loyalty?" Journal of Marketing, Vol. 63 (Special issue), pp. 33-44.

Paparoidamis, N. G. and Caceres, R. C. (2005), "Service Quality, Relationship Satisfaction, Trust, Commitment and Business-to-Business Loyalty," European Journal of Marketing, Vol. 41, No. 7/8, pp. 836-867.

Ranaweera, C. and Prabhu, J. (2003), "The influence of Satisfaction, Trust, and Switching Barriers on Customer Retention in a Continuous Purchasing Setting," International Journal of Service Industry Management, Vol. 14, No. 4, pp 374-395.

Raza, M. A.; Siddiquei, A. N.; Awan, H. N.; and Bukhari, K. (2012), "Relationship Between Service Quality, Perceived Value, Satisfaction and Revisit Intention in Hotel Industry" Interdisciplinary 
Journal of Contemporary Research in Business, Vol. 4, No. 8, pp. 788-805.

Selnes, F. (1998), “Antecedents and Consequences of Trust and Satisfaction in Buyer-Seller Relationships," European Journal of Marketing, Vol. 32 No. 3/4, pp. 305-322.

Weqaiyan, A. (2005), “A Cross National Study of Repurchase Intentions of Fast-Food Meals," Journal of International Food and Agribusiness Marketing, Vol. 17, No. 1, pp. 95-106.
Yang, C. Y. (2009), "The Study of Repurchase Intentions in Experiential Marketing - An Empirical Study of The Franchise Restaurant," The International Journal of Organizational Innovation, Vol. 2, No. 2, pp. 245-261.

Zboja, J. J. and Voorhees, C. M. (2006) "The Impact of Brand Trust and Satisfaction on Retailer Repurchase Intentions," Journal of Services Marketing, Vol. 20, No. 6, pp. 381-390

http://travel.kompas.com/

Persaingan.Perhotelan.di.Yogyakarta.Semakin.

$\underline{\text { Ketat }}$ 